\title{
SUPPLY CHAIN STRATEGIES IN THE CONTEXT OF AN E- COMMERCE CHAIN (E-CHAIN)
}

\author{
João Gilberto Mendes dos Reis \\ Universidade Federal da Grande Dourados - UFGD, Brazil \\ Universidade Paulista - UNIP, Brazil \\ E-mail: betomendesreis@msn.com \\ Pedro Luiz de Oliveira Costa Neto \\ Universidade Paulista - UNIP, Brazil \\ E-mail: politeleia@uol.com.br \\ José Paulo Alves Fusco \\ Universidade Estadual Paulista - UNESP, Brazil \\ E-mail: jpafusco@uol.com.br \\ Sivanilza Teixeira Machado \\ Universidade Federal da Grande Dourados - UFGD, Brazil \\ E-mail: sivateixeira@yahoo.com.br
}

This paper purpose to explore the relationships between supply chain strategies and product performance in retail e-commerce. In this case, we concern that in current, in order to bear up under competition, organizations have to manage their supply chains so that they meet the needs of their final customers. With this concept in mind, the research presented in this study focuses on establishing the right strategy for supply chains according to their product segment. Different strategies can be used such as lean, flexible, responsive and agile. After a Literature Review, the paper explains a methodology based in different authors studies and shows the relationship between supply chain strategy and types of products: functional and innovative. Finally, the article focuses on a case of study in e-commerce retail that describes its application in this field. The use of the right strategy for supply chains will improve the competitive advantage of businesses.

Keywords: e-commerce; supply chain strategy; innovative; functional products. 
INDEPENDENT JOURNAL OF MANAGEMENT \& PRODUCTION (IJM\&P)

http://www.ijmp.jor.br

v. 5, n. 2, February - May 2014.

ISSN: 2236-269X

DOI: 10.14807/ijmp.v5i2.148

\section{INTRODUCTION}

The technological advances have led persons to seek ever more speed of information about quality in supply products and services by companies. In globalized market these companies compete between supply chain and to think in necessity each customer. Thus, everything needs to occur in the least time possible, in a practical way, maintaining the level of quality perceived by the customer.

In this new scenario, consumers are induced to buy their products in the most varied ways, by telephone, stores and Internet. The Internet, in particular, has transformed the way people have access to information, and has been used by companies that wish to improve communication with their suppliers or even develop new supply sources. The Internet is likewise used by consumers who wish to sell, exchange and buy new products. The Internet, operating at network speed, was transformed into an economic medium for carrying out transactions, and conferred the potential for direct electronic distribution (e-distribution) to the customer and among organizations (BOWERSOX et al., 2009).

The Internet has allowed customers to price and choose the most diverse services and products around the world, instantly. E-commerce and global competition has made companies think strategically about their processes in order to manage relationships with customers and suppliers. Customers can use the web to make prices comparisons and check sales conditions, and suppliers can easily be exchanged (LAUDON; LAUDON, 2011). However, the most important part of the process is physical distribution.

Customers want assurances that their products will arrive safely and on time. Thus, to enter in this electronic market it is necessary to analyze supply chain management in a more detailed manner, to understand how products, information and funds are transferred. International business dynamics are essential in supply chain strategies in a global environment (JEONG; HONG, 2007).

Companies have had to make an appraisal and establish a position within their supply chains, including their product and service flows within these chains for the purpose of meeting all the requirements of their customers. Many researchers are studying the challenges of supply chain management in the business environment (CÔRREA, 2010; CHRISTOPHER, 2011; CHOPRA; MEINDL, 2012). 
INDEPENDENT JOURNAL OF MANAGEMENT \& PRODUCTION (IJM\&P)

In this context, supply chain strategies may be different according to the approach taken by network, as in the search for elimination of waste, the ability to make processes more flexible, the ability to respond to markets and agility in serving volatile markets. In effect, these strategies are related to the characteristics of the products made by the network, which may be of an innovative or functional nature (FISHER, 1997; CHRISTOPHER, 2000; LEE, 2002; SELLDIN; OLHAGER, 2007; WU; BARNES, 2010).

Nowadays many different products can be sold by the internet, this products are classified as innovative or functional. In this context, which the best supply chain strategy for internet retail? This paper shows concepts involved in supply chain management strategies and business-to-customer operations and analyze the right supply chain strategy using a methodology based in literature review. The empirical process to apply this methodology was made throughout a case of study in an internet retail.

In addition the objective of this paper can be described as create an empirical methodology to identify the right supply chain strategy to products sold by the internet.

\section{LITERATURE REVIEW}

\subsection{Supply chain}

The supply chain conception started in the 1980s and it has evolved into a very important business concept. Smart (2008) explains that over this time supply chain has been transformed from primarily an operational activity focusing on distribution to a strategic concept which spans functions and crosses interorganizational boundaries.

The definition of supply chain and its components is the first step toward understanding its importance. Many authors have contributed with ideas and definitions on the subject, using a wide range of terms, such as supply chains, organizational networks, and supply networks (PIRES, 2009; SLACK et al., 2010; CÔRREA, 2010; CHRISTOPHER, 2011; CHOPRA; MEINDL, 2012).

There are many ways of understanding and interpreting these definitions. Pires (2009), for example, defines "supply chain" as a network of independent or 
semi-independent companies responsible for obtaining, producing and delivering a determined product or service to the end customer. Slack et al. (2010) affirms that no network exists independently; all operations are part of a larger network, interconnected with other operations. A network consists of a set of relationships between customers and suppliers.

Laudon and Laudon (2011) explain that the supply chain is a network of organizations and business processes to select raw materials to transform them into intermediate and finished products and distribute the finished products to customers. The supply chain connects suppliers, industrial plants, distribution centers, means of transportation, retail stores, and information by means of processes such as selection of raw materials, inventory control, distribution and delivery, for the purpose of providing products and services from the source up to the point of consumption.

\subsection{Supply chain management}

Supply chain management involves a lot more than just cost management since it affects other aspects, such as performance, speed and reliability of deliveries, the quality of the products, and, finally, the flexibility with which the network can adapt (CORREAA, 2010). Thus, supply chain management covers all activities related to the flow and transformation of goods from the raw material stage (extraction) up to the end user, as well as the respective flows of information. So, involves integration of these activities through establishment of improved relationships in the supply chain for the purpose of gaining a sustainable competitive advantage. Integration of all activities in the supply chain allows companies to gain sustainable competitive advantages, advantages which may be produced and maintained (HANDFIELD; NICHOLS, 2002).

Furthermore, supply chain management is management of upstream and downstream relationships with suppliers and customers in order to deliver superior value at the lowest cost for the entire supply chain (CHRISTOPHER, 2011).

\subsection{Supply chain strategies}

Throughout the 20th Century, companies implemented different production strategies, such as agile, responsive, flexible and lean manufacturing (GODINHO FILHO, 2004). This has meant that, over the last few years, many authors, such as 
Vickery et al. (1999), Christopher (2000; 2011), Chase et al. (2005), Pires (2009), Corrêa (2010), Merschmann and Thonemann (2011), have studied different types of management strategies for these networks, proposing that they are directly related to manufacturing paradigms.

Therefore, it is possible to say that these paradigms came to make up the strategies to be adopted by the different supply chains. Thus, what is known as agile manufacturing may be known as an agile supply chain when dealing with the companies present in the network as a whole. The strategies of supply chains depend on the types of products and services that are traded, and also on their supply and demand conditions.

Fisher (1997), creator of the concept of functional and innovative products, says that supply chains suffer from the excess of some products and lack of others, through the inability to forecast demand, and that an effective supply chain strategy goes beyond just considering the nature of demand for company products, but must consider many other aspects, such as the life cycle of the product, predictability of demand, variety of products, standardization of the market in relation to delivery and service time (percentage of demand met by products in stock). Thus Fisher (1997) and Côrrea (2010), classify products, based on standards of demand, in two categories:

- Functional products: these are products which satisfy basic needs of the consumer and which do not change much over time, having stable and predictable levels of demand and long life cycles. This stability generates competition, which in turn leads to low profit margins.

- Innovative products: these are the products which, through innovation and technology, become popular at certain times and generate, for the consumer, an additional attraction to buy these products. This leads to an increase in profit margins. However, the demand for these products is unpredictable, the life cycle is short (only a few months) and they suffer from imitations from other companies, which reduce or even eliminate the original competitive edge, making the company live in cycles of innovations. 
It is necessary to establish if products are functional or innovative, even though this may be done by managers based on the products with unstable and stable demand (Table 1)

Table 1 - Functional versus innovative products

\begin{tabular}{lcc}
\hline Features & Functional & Innovative \\
\hline Aspects of demand & Predictable & Unpredictable \\
\hline Product life cycle & More than 2 years & 3 months to 1 year \\
\hline Contribution margin & $5 \%$ to $20 \%$ & $20 \%$ to $60 \%$ \\
\hline $\begin{array}{l}\text { Product variety } \\
\text { Average margin of error in the forecast } \\
\text { at the time production is committed }\end{array}$ & $\begin{array}{c}10 \% \\
\text { category) }\end{array}$ & $\begin{array}{c}\text { High (often millions of } \\
\text { variants per category) }\end{array}$ \\
\hline $\begin{array}{l}\text { Average stockout rate } \\
\begin{array}{l}\text { Average forced end-of-season } \\
\text { markdown as percentage of full price }\end{array}\end{array}$ & $0 \%$ & $40 \%$ to $100 \%$ \\
\hline $\begin{array}{l}\text { Lead time required for made-to-order } \\
\text { products }\end{array}$ & 6 months to 1 year & $10 \%$ to $40 \%$ \\
\hline
\end{tabular}

Source: Adapt of Fisher 1997

Fisher (1997) says that companies must to be sure determine whether their products are functional or innovative to be sure the right approach about supply chain strategy. In his vision we are able to apply two types of strategy: Efficient Supply Chain Strategy and Responsive Supply Chain Strategy. However, before we need to decide whether company's supply chain is Physically Efficient Process (PEP) or Market Responsive Process (MRP). Table 2 shows the comparison between one and another. 
INDEPENDENT JOURNAL OF MANAGEMENT \& PRODUCTION (IJM\&P)

http://www.ijmp.jor.br

v. 5, n. 2, February - May 2014.

ISSN: 2236-269X

DOI: 10.14807/ijmp.v5i2.148

Table 2 - Physically efficient process versus Market responsive process

\begin{tabular}{|c|c|c|}
\hline Features & PEP & REP \\
\hline Primary Purpose & $\begin{array}{l}\text { supply predictable demand } \\
\text { efficiently at the lowest possible cost }\end{array}$ & $\begin{array}{l}\text { Respond quickly to unpredictable } \\
\text { demand in order to minimize } \\
\text { stockouts, force markdowns and } \\
\text { obsolete inventory }\end{array}$ \\
\hline Manufacturing Focus & Maintain high average utilization rate & Deploy excess buffer capacity \\
\hline Inventory Strategy & $\begin{array}{l}\text { Generate right turns and minimize } \\
\text { inventory throughout the chain }\end{array}$ & $\begin{array}{l}\text { Deploy significant buffer excess } \\
\text { stock of parts and finished goods }\end{array}$ \\
\hline Lead Time Focus & $\begin{array}{l}\text { Short lead time as long as it doesn't } \\
\text { increase costs }\end{array}$ & $\begin{array}{l}\text { Invest aggressively in ways to } \\
\text { reduce lead time }\end{array}$ \\
\hline $\begin{array}{l}\text { Approach to Chossing } \\
\text { Suppliers }\end{array}$ & Select primarly for cost and quality & $\begin{array}{l}\text { Select primarly for speed, flexibility } \\
\text { and quality }\end{array}$ \\
\hline $\begin{array}{l}\text { Product Design } \\
\text { Strategy }\end{array}$ & $\begin{array}{l}\text { Maximaze performance and } \\
\text { minimize cost }\end{array}$ & $\begin{array}{l}\text { Use a modular design in order to } \\
\text { postpone product differentiation for } \\
\text { as long as possible }\end{array}$ \\
\hline
\end{tabular}

Source: Adapt Fisher (1997)

Christopher and Towil (2000), Pires (2009) classify supply chain strategy in Lean Supply Chain and Agile Supply Chain. The made a comparison of attributes between Lean and Agile Supply Chain (Table 3).

Lee (2002) connected this study in a matrix that consider supply and demand uncertainties related to supply chain strategies and also to types of products. Subsequently, authors such as Chase et al. (2005) and Corrêa (2010) lent great prominence to this contribution (Figure 1).

Table 3 - Comparasion of lean supply chain and agile supply chain

\begin{tabular}{lcc}
\hline Distiguishing attributes & Lean Supply Chain & Agile Supply Chain \\
\hline Typical products & commodities & Fashing goods \\
\hline Marketplace demands & predictable & volatile \\
\hline Product variety & low & high \\
\hline Product life cycle & long & short \\
\hline Customer drives & cost & availability \\
\hline Profit margin & low & high \\
\hline Dominant costs & Physical costs & Marketability costs \\
\hline Stockout penalties & Long term contractual & Immediate and volatile \\
\hline Purchasing police & Buy goods & Assign capacity \\
\hline Information enrichment & Highly desirable & obligatory \\
\hline Forecasting mechanism & algorithmic & consultative \\
\hline
\end{tabular}

Source: Adapt Christopher and Towil (2000) 
INDEPENDENT JOURNAL OF MANAGEMENT \& PRODUCTION (IJM\&P)

http://www.ijmp.jor.br

v. 5, n. 2, February - May 2014

ISSN: 2236-269X

DOI: 10.14807/ijmp.v5i2.148

\begin{tabular}{|c|c|c|c|}
\hline & \multicolumn{2}{|c|}{ Demand Uncertainty } \\
\hline & & Low (Functional Products) & High (Innovative Products) \\
\hline \multirow{2}{*}{ 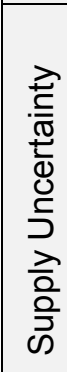 } & Low (Stable Process) & $\begin{array}{c}\text { Grocery, basic apparel, } \\
\text { food, oil and gas } \\
\text { Efficient or Lean Supply } \\
\text { Chains }\end{array}$ & $\begin{array}{l}\text { Fashion apparel, computers, } \\
\text { pop music } \\
\text { Responsive Supply Chains }\end{array}$ \\
\hline & High (Evolving Process) & $\begin{array}{c}\text { Hydro-electric power, } \\
\text { some food produce } \\
\text { Risk-Hedging or Flexible } \\
\text { Supply Chains }\end{array}$ & $\begin{array}{l}\text { Telecom, high-end } \\
\text { computers, semiconductors } \\
\text { Agile Supply Chains }\end{array}$ \\
\hline
\end{tabular}

Figure 1 - Uncertainties and Supply Chains Strategies.

Source: adapt Lee (2002)

According to the model proposed by Lee (2002), supply chains are divided up into four types: lean or efficient supply chains; responsive supply chains; supply chains with minimum or flexible risk, treated as flexible supply chains; and agile supply chains.

\subsection{Lean supply chains}

According to Womack et al. (2007), new ideas emerge from the set of conditions under which the old ideas no longer seem to work. This fact explains why the Japanese auto industry has brought so many contributions to production. The lean way of thinking to produce without waste, together with development of quality, has provided a competitive advantage to those companies.

Lean thinking was responsible for major change in the production paradigm in the 20th Century. Naylor et al. (1999) state that this concept consists of development of a continuous flow of value to eliminate all waste, including waste of time. This thinking is translated in the Toyota Production System (TPS), whose focus, according to Agarwal et al. (2006), lies in the reduction and elimination of waste.

Lean manufacturing is a new approach that offers a better way of organizing and managing company relationships with customers, the supply chain, product development and production operations, using ever fewer resources in production operations (WOMACK et al. 2007). That way, the lean approach may be applied throughout the Supply Chain, reducing losses by business partners within these networks. This can be remarkably important when dealing with products with low levels of profitability. 
DOI: 10.14807/ijmp.v5i2.148

\subsection{Flexible supply chains}

Flexibility was a concept that emerged from the industry, based on the Toyota Production System. After the Second World War, Japan lacked resources for production. Companies did not have enough capital to acquire the same amount of machinery and equipment to compete with the mass production industries of the Western world, so they had to have flexibility to optimize their productive activities (WOMACK et al., 2007).

The success achieved by Japanese companies such as Toyota, and subsequent technological development, was what made flexibility concepts known throughout the world, and after that, they came to be used by many researchers in various aspects of operations management. These concepts have especially been used in contributions involving supply chain processes.

Gong (2008) says that manufacturing companies, faced with keen competition, have developed the ability of dealing with internal and external uncertainties by making use of flexibility. This is a goal to pursue within organizations.

To understand the concept of flexible supply chains, it is necessary to understand what flexibility means. According to Upton (1994), flexibility can be defined as the ability to change or react with little penalty in time. On the other hand Fusco (2004) argues that flexibility reflects the actual situation of a company, a set of capabilities intrinsic to it, and the result or final potential of handling changes (planned or not) in a broader scenario.

When the issue is a network of companies, flexibility in operations is essential to existence in the market. A supply chain cannot be something immutable; it is necessary that the organization have flexibility in its operations rapidly, whether in production, logistics, marketing or supply. That is only possible through exchange of information in the various links of the chain. According to Vickery et al. (1999), the flexibility of supply chains may well represent a potential source for improving company efficiency, and it is a significant measure of the performance of the supply chain. 


\subsection{Responsive supply chains}

The time factor is crucial in any logistics operation since any good or service will only have value when it is available to the customer at the right time and place. According to Ballou (2003), the mission of supply chain management is placing the right products or services in the right time, at the right place, in the desired condition, thus allowing a higher contribution to the company. At the same time, it is important to achieve this condition without the need for increasing the quantities of stock in the supply chain, which, according to Ballou (2003), may represent from $12 \%$ to $40 \%$ of all logistics costs. The challenge of the responsive supply chain model is to identify ways of becoming faster in responding to its main goal, which is, customer service and maintenance of service costs at acceptable levels.

What supports a responsive supply chain or, as some authors describe, the logistics of rapid response, is the use of competitive advantages based on time, using systems that are responsive and fast (CHRISTOPHER, 2011). Stalk and Hout (2003) argue that for a responsive strategy, it is necessary that the company direct its efforts to customers most sensitive to the question of time. In a supply chain oriented to e-commerce, customers do not receive the product at the time of purchase. Thus, delivery time is essential to the process.

The main difference between the responsive supply chain and the agile supply chain is that the former considers operational and production costs within the context of the supply chain (GUNASEKARAN et al., 2008).

\subsection{Agile supply chains}

Martin Christopher was one of the first to introduce the concept of agility in the supply chain, in an article he wrote in the year 2000, "The agile supply chain" (CHRISTOPHER, 2000), and also in his book "Logistics and Supply Chain Management" which came out at the end of the 1990s (CHRISTOPHER, 2011). These works were followed by a series of research studies which were published in several periodicals, studies considered as fundamental for the concept of the agile supply chain. These studies are cited and used by several researchers in a variety of periodicals, including, among others, the research studies conducted by Power et al. (2001), Ismail and Sharifi (2006), Ramesh and Devadasan (2007), Luo et al. (2009), Wu and Barnes (2010). 
INDEPENDENT JOURNAL OF MANAGEMENT \& PRODUCTION (IJM\&P)

http://www.ijmp.jor.br

v. 5, n. 2, February - May 2014.

ISSN: 2236-269X

DOI: 10.14807/ijmp.v5i2.148

According to Kidd (1994), agile manufacturing can be considered a structure within which each company is able to develop its own business strategies and products, being supported by three pillars: organization, people and technology. The study of agility of companies arises in the manufacturing sector in the early $90 \mathrm{~s}$, linked with the term agile manufacturing. The concept was popularized by a group of professors from the laccoca Institute in the United States after the publication of a report involving more than 150 executives from industry, describing how American competitiveness would be developed in the next 15 years (GODINHO FILHO, 2004).

Agile manufacturing is the ability to survive and thrive in a competitive environment, with rapid service and punctuality as the main objective. According to Pires (2009), the word "agile" means a focus on achieving a productive system that is able to adapt and respond quickly to market changes, i.e., it is more responsive. The author argues that the main characteristics of the agile supply chain (SC) are flexibility and availability.

On the other hand, for Krajewnski et al. (2012), the focus of agile supply chains is reaction time, with the goal of avoiding costly inventories that end up being sold at major discounts. The objective is maintaining availability to the customer and avoiding the depletion of stocks, avoiding, at the same time, losses through obsolescence of products.

\subsection{E-business}

Nowadays e-commerce has the potential to revolutionize the way a business is run (SHARIFI et al., 2012). In fact, e-commerce has evolved in the last few years into a wide range of relationships known as e-business, making it possible to increase the speed of the order cycles. As a result, customers can do business more easily than ever, particularly when a mix of price, quality, and speed of response represents an important requirement.

Laudon and Laudon (2011) refer to the concept of e-business or electronic business as the use of digital technology and the Internet to carry out the main business processes of a company. Smart (2012) presents the importance of applying new mechanisms of e-business to compose supply chains. Relationships between companies and consumers may occur in four ways, according to Slack et al. (2010): 
INDEPENDENT JOURNAL OF MANAGEMENT \& PRODUCTION (IJM\&P)

http://www.ijmp.jor.br

v. 5, n. 2, February - May 2014.

ISSN: 2236-269X

DOI: 10.14807/ijmp.v5i2.148

- Business to Business (B2B): in which one organization may undertake electronic transactions with another. This is a very common practice between retailers of a hypermarket that adopt electronic purchasing systems and their suppliers, known as EDI - Electronic Data Interchange, to facilitate replacement of their merchandise.

- Customer to Business (C2B): in which the customer relates to businesses, defining his intentions of consumption, such as price and characteristics of the products, and the organizations decide whether to serve that demand generated under the conditions requested. Can involve some operators of airline tickets and reservation sites.

- Business to Customer (B2C): in which companies create Internet portals to sell their products, opening another channel of relationship with their customers and reducing the costs of making products available on the physical market.

- Customer to Customer (C2C): consists of the relationship between consumers through the virtual environment. This involves the exchange portals between consumers and electronic auction, such as "e-bay", in which Internet users can announce and sell their products.

\section{METHODOLOGY}

The purpose of this work is create a methodology to identify the right supply chain strategy in e-commerce context. For development of the methodology of this study, the following procedures were adopted:

(a) A review of the literature was developed to understand the supply chain strategies, as well as concepts that allow development of a methodology for creating a typology for product relationship and supply chain strategy.

(b) Based on the studies of Fisher (1997), Christopher and Towil (2000), Lee (2002), Chase et al. (2005), Pires (2009) and Corrêa (2010), a table was developed with the characteristics that allow classification of the product in relation to the supply chain strategy to be applied (Table 4). To identify the right supply chain to apply we need identify all characteristics presents in Table 4 about the product chosen. Consequently using this datas we check all 
INDEPENDENT JOURNAL OF MANAGEMENT \& PRODUCTION (IJM\&P)

http://www.ijmp.jor.br

v. 5, n. 2, February - May 2014.

ISSN: 2236-269X

DOI: 10.14807/ijmp.v5i2.148

row of table evaluating the product. Finally, to determine the right supply chain strategy we consider the number of answers. For instance, a product with more characteristics of column two need a lean supply chain strategy, column three flexible and so on.

Table 4 - Supply chain strategies aligned with product characteristics

\begin{tabular}{|c|c|c|c|c|}
\hline Item & Lean SC & Flexible SC & Responsive SC & Agile SC \\
\hline $\begin{array}{l}\text { Typical } \\
\text { Products }\end{array}$ & $\begin{array}{c}\text { Grocery, } \\
\text { basic apparel, } \\
\text { food, oil and } \\
\text { gas }\end{array}$ & $\begin{array}{l}\text { Hydro-electric } \\
\text { power, some } \\
\text { food produce }\end{array}$ & $\begin{array}{c}\text { Fashion apparel, } \\
\text { computers, pop } \\
\text { music }\end{array}$ & $\begin{array}{c}\text { Telecom, high-end } \\
\text { computers, } \\
\text { semiconductors }\end{array}$ \\
\hline Demand & Predictable & Predictable & Volatile & Volatile \\
\hline $\begin{array}{l}\text { Variety of } \\
\text { Products }\end{array}$ & Low & Low & High & High \\
\hline $\begin{array}{l}\text { Product Life } \\
\text { Cycle }\end{array}$ & Long & Long & Short & Short \\
\hline $\begin{array}{l}\text { Customer } \\
\text { Drivers }\end{array}$ & $\begin{array}{c}\text { Cost and } \\
\text { Quality }\end{array}$ & $\begin{array}{l}\text { Cost and } \\
\text { Quality }\end{array}$ & Availability & Availability \\
\hline Profit Margin & Low & Low & High & High \\
\hline $\begin{array}{c}\text { Dominant } \\
\text { Costs }\end{array}$ & $\begin{array}{c}\text { Physical } \\
\text { Costs }\end{array}$ & Physical Costs & Marketing Costs & Marketing Costs \\
\hline $\begin{array}{c}\text { Supply } \\
\text { Uncertainty }\end{array}$ & Low & High & Low & High \\
\hline $\begin{array}{l}\text { Purchase } \\
\text { police }\end{array}$ & Buy goods & Buy goods & Assign capacity & Assign capacity \\
\hline $\begin{array}{l}\text { High Quality of } \\
\text { information, } \\
\text { especially } \\
\text { about demand }\end{array}$ & $\begin{array}{c}\text { Highly } \\
\text { desirable }\end{array}$ & $\begin{array}{c}\text { Highly } \\
\text { desirable }\end{array}$ & Obligatory & Obligatory \\
\hline $\begin{array}{c}\text { Forecast } \\
\text { Mechanism }\end{array}$ & Algorithm & Algorithm & Advisory & Advisory \\
\hline $\begin{array}{l}\text { Type of } \\
\text { product }\end{array}$ & Functional & Functional & Innovative & Innovative \\
\hline
\end{tabular}

(c) Furthermore, this work has objective study internet market, so we apply our methodology in a case of study in electronic business company of the B2C type. Seuring (2008) says that a case of study is more suitable when conducting business research. We sought to characterize the company and show the product classification methodology in relation to the supply chain strategy for the purpose of showing how the company can classify its diverse products in one of the four categories to align its sales and distribution strategies so as to meet customer requirements and gain a competitive advantage. 


\section{RESULTS AND DISCUSSION}

\subsection{Case of study}

The company researched was founded in the city of Niteroi, Rio de Janeiro in 1929 by a group of Americans who came from the U.S. to open a "Five and Ten Cent" store in Buenos Aires. This was a specific kind of store that was very successful in the United States and Europe for selling low price products. However, during their trip on the ship, they met some Brazilians who invited them to visit Rio de Janeiro and they ended up staying there. At the end of the first year, there were three stores in Rio and one in São Paulo.

At the end of 1999, the company entered the e-commerce market with the creation of a subsidiary formed by six other companies that held shares representing $33 \%$ of the capital stock of this new company. Expansion of the department store continued in 2003. In addition to the opening of more physical stores, they opened other compact stores known as Express Shops. In 2005, they acquired a TV channel with the same name as their e-commerce site, and created a joint venture with a wellknown bank in order to carry out loans and financing in their stores.

In 2006, a company was created to manage the merger of their portals with another recently acquired one, then maintaining a $53.25 \%$ stake of the capital. In 2007, they acquired a well- known brand for video rental, in which, in addition to exploiting the physical network, they will utilize the brand by renting films through the Internet starting in 2008. The division of the companies in the group is shown in Figure 2.

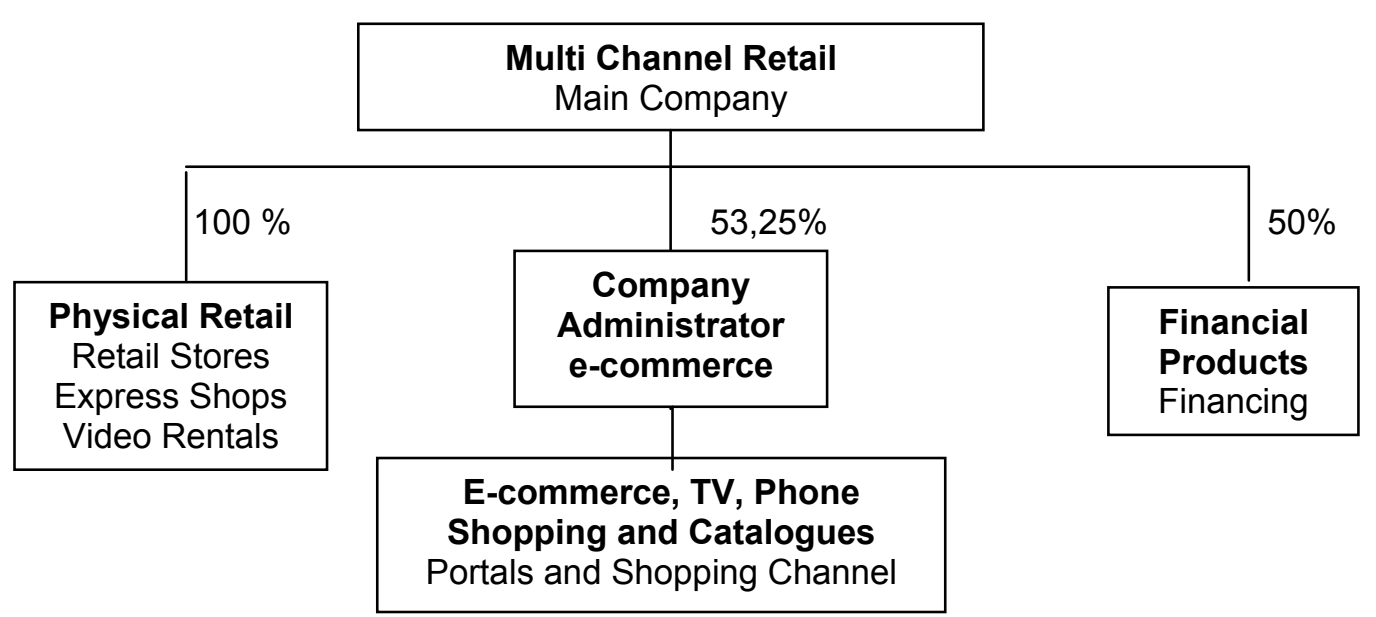

Figure 2 - Composition of the business of the company researched 
The company sells various types of products in 36 departments, such as food and drinks, home appliances, electronics, furniture, stationery, computer products and others. Certainly, each type of product establishes different strategic needs, in other words, there are products that are more functional and require lean and flexible network strategies and there are more innovative products that require more responsive or agile strategies.

Due to the variety of products that the retailer has available on the market, there will evidently be products classified in all the strategies. The idea proposed in this article is to make it possible for the company to classify these products through the proposed methodology and thus adopt the strategies corresponding to each class of product. As an illustration of the application of the model, two products offered by the company were chosen: dairy products and notebooks. The characteristics of the two types of products may be described in Table 5 .

Table 5 - Type of products analyzed in supply chain strategy context

\begin{tabular}{ccc}
\hline Aspects & Product 1 & Product 2 \\
\hline Basic Products & Dairy Products & Notebooks \\
\hline Demand & Predictable & Predictable \\
\hline Variety of Products & Low & High \\
\hline Product Life Cycle & Long & Short \\
\hline Criteria of Winning Orders & Cost and Quality & Availability \\
\hline Profit Margin per unit & Low & Low \\
\hline Dominant Costs & Physical Costs & Marketing Costs \\
\hline High Quality of information, especially & Highly desirable & Obligatory \\
\hline about demand & Algorithm & Advisor \\
\hline Forecast Mechanism &
\end{tabular}

To determine the characteristics of the types of products, information obtained from the company by various means were used, such as interviews, management reports and accounting documents. Based on these data, the characteristics of each one of the products may be established. These data present in Table 3 are cross referenced with the data from Table 2 .

\subsection{Discussion}

Concerning to results from interaction between characteristics expected and observed of goods at company this study of case, it is possible to determinate some points of view, as following: 
INDEPENDENT JOURNAL OF MANAGEMENT \& PRODUCTION (IJM\&P) http://www.ijmp.jor.br v. 5, n. 2, February - May 2014. ISSN: 2236-269X

DOI: 10.14807/ijmp.v5i2.148

(a) Dairy products are classified as functional products with predictable demand and low uncertainty of demand; therefore, they need a lean supply chain strategy, with a view toward eliminating losses that have a direct impact on their results.

(b) Notebooks have a volatile demand; however, they are in a mature production stage, which reduces the supply uncertainties. Their sale depends on the availability of the models on the market, and may thus be characterized as an innovative product which requires a responsive supply chain strategy.

Therefore, for the electronic retail company, it is necessary to align the supply chain strategy of the dairy products in a lean strategy, eliminating waste, which involves more agile logistics, reduction of stock, elimination of redundant operations and continual flow, among other practices.

In regard to notebooks, a responsive strategy is suitable; in other words, the supply chain should be aligned so as to reduce response time, which is essential for electronic commerce since, if the chain is not able to meet the needs in the least time possible, it will lose the competition to a traditional retail supply chain. This requires the use of computational tools and rapid response logistics to meet customer demands. However, one must not lose track of costs, the key point for responsive supply chains, because the margins of the products in this stage of development are less than those characterized in the context of the agility, which allows a greater operating cost.

Thus, the methodology needs to be determined for the diverse products sold by the company so as to apply the correct strategy for each group of products, allowing effective management of their supply chains.

The methodology presented in this paper will hardly respond to all the questions proposed for it, as seen in the survey that was carried out. However, it is possible to see some convergence, which allows companies to prepare more profitable strategies compared to the traditional ones. The methodology presented is not immutable and it can be extended by the inclusion of other factors that could be examined through new research or practical applications in the business world. Another factor to be considered, also in future research, would be the applicability of 
mixed operations in supply chain strategies, such as use of the "leagile" concept, which corresponds to a strategy concept where the supply chain is lean in the early stages and becomes agile more toward the end of the product and service delivery process.

\section{CONCLUSION}

Based on the characteristics identified in the study, it was possible to conclude that an e-commerce supply chain varies according to the product and segment in focus. This fact leads us to consider that it is not possible to establish a fixed model for the entire operations network; on the contrary, it is necessary to develop segmented strategies for each supply chain and specific groups of products.

E-commerce companies that adopt differentiated supply chain strategies for each product may possibly acquire advantages over those companies that do not operate in this manner. It is important to consider that for each product there is a different way of reaching the customer. This could be better established if market research were made to analyze the typical priorities of each specific segment of the consumer market in e-commerce.

E-commerce increase demand and product variety year by year, so its important the all supply chain follow this scenario acting in the right context, for instance whether products are commodities and had short profit margin the companies need adopt lean supply chain strategies to be competitive.

We believe that this paper reached the objective to show a methodology to identify the right supply chain strategy. As the focus was the internet scenario we presented a case of study using a e-commerce retail in Brazil. The purpose of case of study was illustrated the methodology, next step of research is evaluated different companies in this segment to determine the scope of the methodology developed here.

One limitation is that the methodology study focuses on only two e-commerce segment; future studies may go further in refining the proposed framework for other segments. 


\section{REFERENCES}

AGARWAL, A.; SHANKAR, R.; TIWARI, M. K. (2006) Modeling the metrics of lean, agile and leagile supply chain: an ANP-based approach, European Journal of Operations Research, v. 173, n. 1, p. 211-225.

BALLOU, R.H. (2003), Business Logistics: Supply Chain Management, Prentice Hall: Upper Saddler River, NJ.

BOWERSOX, D. J.; CLOSS, D. J.; COOPER M. B. (2009) Supply Chain Logistics Management, McGraw-Hill: New York, NY.

CHASE, R. B.; JACOBS, F. R.; AQUILANO, N. J. (2005) Operations Management for Competitive advantage, McGraw-Hill: New York, NY.

CHOPRA, S.; MEINDL, P. (2012) Supply Chain Management: Strategy, Planning and Operation, Prentice Hall: Upper Saddler River, NJ.

CHRISTOPHER, M.; TOWIL, D. R. (2000) Supply chain migration from lean and functional to agile and customized, Supply Chain Management: An International Journal, v. 5, n. 4, p 206-213.

CHRISTOPHER, M. (2011) Logistics and Supply Chain Management, FT Press: Upper Saddler River, NJ.

CHRISTOPHER, M., (2000) The agile supply chain: competing in volatile markets, International Marketing Management, v. 29, p. 37-44.

CORREAA, H. L. (2010) Supply Network Management, Atlas: São Paulo.

SELLDIN, E.; OLHAGER, J. (2007) Linking products with supply chains: testing Fisher's model, Supply Chain Management: An International Journal, v. 12, n. 1, pp. 42-51.

FISHER, M. (1997) What is the right supply chain for your product?, Harward Business Review, March-April 1997, p. 105-115.

FUSCO, J. P. A, (2004) Supply Chain and Enterprises Network, Arte e Ciência: São Paulo.

GODINHO FILHO, M.; FERNANDES, F. C. F. (2009) Strategic Paradigms for Manufacturing Management (SPMM): Key elements and conceptual model, International Journal of Industrial Engineering: theory, applications and practice, v. 16, n. 2, p. 147-159.

GONG, Z. (2008) An economic evaluation model of supply chain flexibility, European Journal of Operation Research, v. 184, p. 745-758.

GUNASEKARAN, A.; KEE-HUNG, L.; CHENG, T. C. E. (2008) Responsive supply chain: a competitive strategy in a networked economy, The International Journal of Management of Science, v. 36, p. 549-564.

HANDFIELD, R. B.; NICHOLS, E. L. (2002) Supply Chain Redesign: Transforming Supply Chains into Integrated Value Systems, FT Press: Upper Saddler River, NJ. ISMAIL, H. S.; SHARIFI, H. (2006) A balanced approach to building agile supply chains, International Journal of Physical Distribution \& Logistics Management, v. 36, n. 6, p. $431-444$. 
JEONG, J. S.; HONG, P. (2007) Customer orientation and performance outcomes in supply chain management, Journal of Enterprise Information Management, v. 20, n. 5, p. 578-594.

KIDD, P. T. (1994) Agile Manufacturing, Addison-Wesley: New York, NY. KRAJEWSKI, J. L.; RITZMAN, L. P.; MALHOTRA, M. K. (2012) Operations Management: Processes and Supply Chains, Prentice Hall: Upper Saddler River, NJ.

LAUDON, K. C.; LAUDON, J. P. (2011) Management Information System, Prentice Hall: Upper Saddler River, NJ.

LEE, H. L. (2002) Aligning supply chain strategies with product uncertainties, California Management Review, v. 44, n. 3, p. 105-119.

LUO, X.; WU, C.; ROSENBERG, D.; BARNES, D. (2009) Supplier selection in agile supply chains, an information-processing model and illustration, Journal of Purchasing \& Supply Chain Management, v. 15, p. 249-262.

MERSCHMANN, U.; THONEMANN, U. W. (2011) Supply chain flexibility, uncertainty and firm performance: an empirical analysis of German manufacturing firms,

International Journal of Production Economics, v. 130, p. 43-53.

NAYLOR, J. B.; MOHAMED, M. N.; BERRY, D. (1999) Leagility: integration of the lean and agile manufacturing paradigms, International Journal of Production Economics, v. 62, p. 107-118.

PIRES, S. R. I. (2009) Supply Chain Management, Atlas: São Paulo.

POWER, D. J.; SOHAL, S. A.; RAHMAN, S. U. (2001) Critical success factors in agile supply chain management: an empirical study, International Journal of Physical Distribution \& Logistics, v. 31, n. 4, p. 247-265.

RAMESH, G.; DEVADASAN, S. R. (2007) Literature review on the agile manufacturing criteria, Journal of Manufacturing Technology Management, v. 18, n. 2, p. 182-201.

SEURING , S. A. (2008) Assessing the rigor of case study research in supply chain management, Supply Chain Management : An International Journal, v. 13 n. 2 , p. 128-137.

SHARIFI, H.; ISMAIL, H. S.; REID, I. (2006) Achieving agility in supply chain through simultaneous design of and design for supply chain, Journal of Manufacturing Technology Management, v. 17, n. 8, p. 1078-1098.

SLACK, N.; CHAMBERS, S.; JOHNSTON, R. (2010) Operations Management, Prentice Hall: Upper Saddler River, NJ.

SMART, A. (2008) E-Business and supply chain integration, Journal of Enterprise Information Management, v. 21, n. 3, p. 227-246.

STALK, G.; HOUT, T. (2003) Competing Against Time, The Free Press: New York, NY.

UPTON, D. M. (1994) The management of manufacturing flexibility, California Management Review, v. 36, n. 2, p. 72-89. 
VICKERY, S.; CALATONE, R.; DROGE, C. (1999) Supply chain flexibility: an empirical study, International Journal of Operations and Production Management, v. 35, n. 1, p.16-24.

WOMACK, J. P.; JONES, D. T.; ROOS D. (2007) The Machine That Changed the World: The Story of Lean Production: Toyota's Secret Weapon in the Global Car Wars that is Now Revolutionizing World Industry, Free Press: New York, NY.

WU, C.; BARNES, D. (2010) Formulating partner selection criteria for agile supply chains: a dempster-shafer belief acceptability optimisation approach, International Journal of Production Economics, v.125, p. 284-293. 